\title{
Phimophis guerini (Duméril, Bibron and Dumeril, 1854) (Serpentes: Dipsadidae): Distribution extension in Paraiba,
} Brazil

\author{
Gentil Alves Pereira Filho ${ }^{1}$, Gindomar Gomes Santana ${ }^{1}$, Washington Luiz da Silva Vieira ${ }^{1}$, \\ Rômulo Romeu da Nóbrega Alves ${ }^{2}$, Paulo Fernando Guedes Pereira Montenegro ${ }^{1}$ and \\ Marco Antônio de Freitas ${ }^{3^{*}}$ \\ 1 Universidade Federal da Paraíba, Centro de Ciências Exatas e da Natureza, Programa de Departamento de Sistemática e Ecologia. CEP 58059-900. \\ João Pessoa, PB, Brazil. \\ 2 Universidade Estadual da Paraíba, Departamento de Biologia. Av. das Baraúnas, 351 Bodocongó. CEP 58109-753. Campina Grande, PB, Brazil. \\ 3 Instituto Chico Mendes de Conservação da Biodiversidade (ICMBio). REBIO Gurupi. BR 222, KM 12, S/N, Pequiá. CEP 65930-000. Açailândia, MA, \\ Brazil. \\ * Corresponding author. E-mail: philodryas@hotmail.com
}

ABSTRACT: We provide a new record of Phimophis guerini from the Atlantic Forest in Paraiba state and a review of the distribution of the species.

The genus Phimophis Cope, 1860 comprises three species of nocturnal, terrestrial and subterranean dipsadid snakes distributed from Panama to Argentina, through Colombia, the Guiana Region and Brazil (Peters and Orejas-Miranda 1970, Tipton 2005; Grazziotin et al. 2012). In Brazil there are two species: P. guerini and $P$. guianensis. Both species are restricted to open formations such as Cerrado, Cerrado enclaves in the Amazon region and Caatinga. Here we report the second record of $P$. guerini for the region of Coastal Atlantic Forest (Freitas 2003; Lisboa et al. 2011).

During a herpetological inventory from June 2007 to February 2008 at Mata do Açude do Cafundó (07¹0'51" $\left.\mathrm{S}, 35^{\circ} 05^{\prime} 37^{\prime \prime \prime} \mathrm{W}, 91 \mathrm{~m}\right)$, a fragment of Atlantic Forest in the municipality of Cruz do Espirito Santo, Paraíba state, we collected an individual of Phimophis guerini. The specimen (Figure 1), a young female, was captured during the night, on the forestfloor, and measures $360 \mathrm{~mm}$ total length and 60 $\mathrm{mm}$ tail length. It has the following scutellation: one loreal, one preocular, two postoculars, eight supralabials (fourth and fifth in contact with the orbit), nine infralabials, $2+3$ temporals, 19-19-17 dorsal scale rows, 204 ventrals and 68 single subcaudals. The specimen was collected under permit number 133/06 - IBAMA/RAN issued by IBAMA. The specimen is housed at the Coleção Herpetologica do Departamento de Sistemática e Ecologia da Universidade Federal da Paraíba (UFPB 4796)

One other specimen was found dead on road BR 101 in the municipality of Rio Tinto in June $2009\left(07^{\circ} 04^{\prime} 42^{\prime \prime}\right.$ $\mathrm{S}, 34^{\circ} 59^{\prime} 13^{\prime \prime} \mathrm{W}, 88 \mathrm{~m}$ ). This specimen is housed at Universidade Estadual de Santa Cruz (MZUESC 8169).

In Brazil Phimophis guerini is distributed in south Piauí, Amazonas, Mato Grosso, south São Paulo and Goiás states (Peters and Orejas-Miranda 1970). There are others records in Distrito Federal (França et al. 2008) and Cerrado enclaves in the Amazon region (França at al. 2006). Sawaya et al. (2008) reports this snake in the municipality of Itirapina, São Paulo state. It also occurs in the Atlantic forest of Alagoas (Lisboa et al. 2011), Minas Gerais (Recorder and Nogueira 2007), Tocantins (Vitt et al. 2005), and Paraná (Bérnils and Moura-Leite 2010). In Bahia state, there are records in Chapada Diamantina (Caatinga domain) (Juncá 2005), and in the municipalities of Mata de São João, Santa Terezinha and Elíseo Medrado (Freitas 2003). In Argentina, P. guerini occurs in the provinces of Misiones, Corrientes, Entre Rios, Santa Fe, Chaco, Tucumán and southwestern Cordoba (Peters and Orejas-Miranda 1970; Tipton 2005). The specimens in this study extend the distribution $360 \mathrm{~km}$ northeast of the nearest location in Alagoas (Lisboa et al. 2011). All the records mentioned here show that $P$. guerini inhabits primarily open formations but is also found in some regions of Atlantic Forest. Due to its scarcity in herpetological collections (Rodrigues 1993) the distribution of this snake is not completely known.

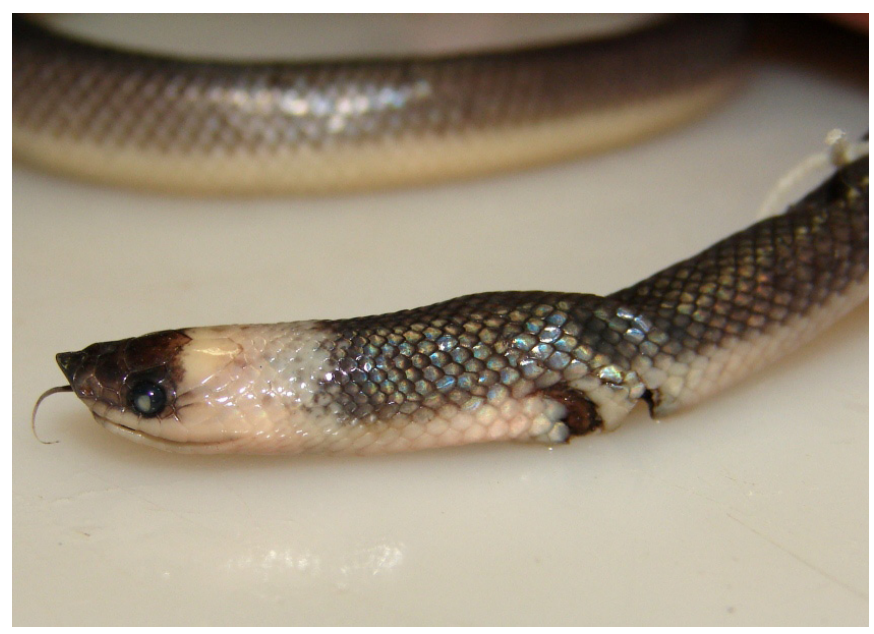

FIGURE 1. Phimophis guerini UFPB 4796 collected in Cruz do Espirito Santo, Paraiba, Brazil 


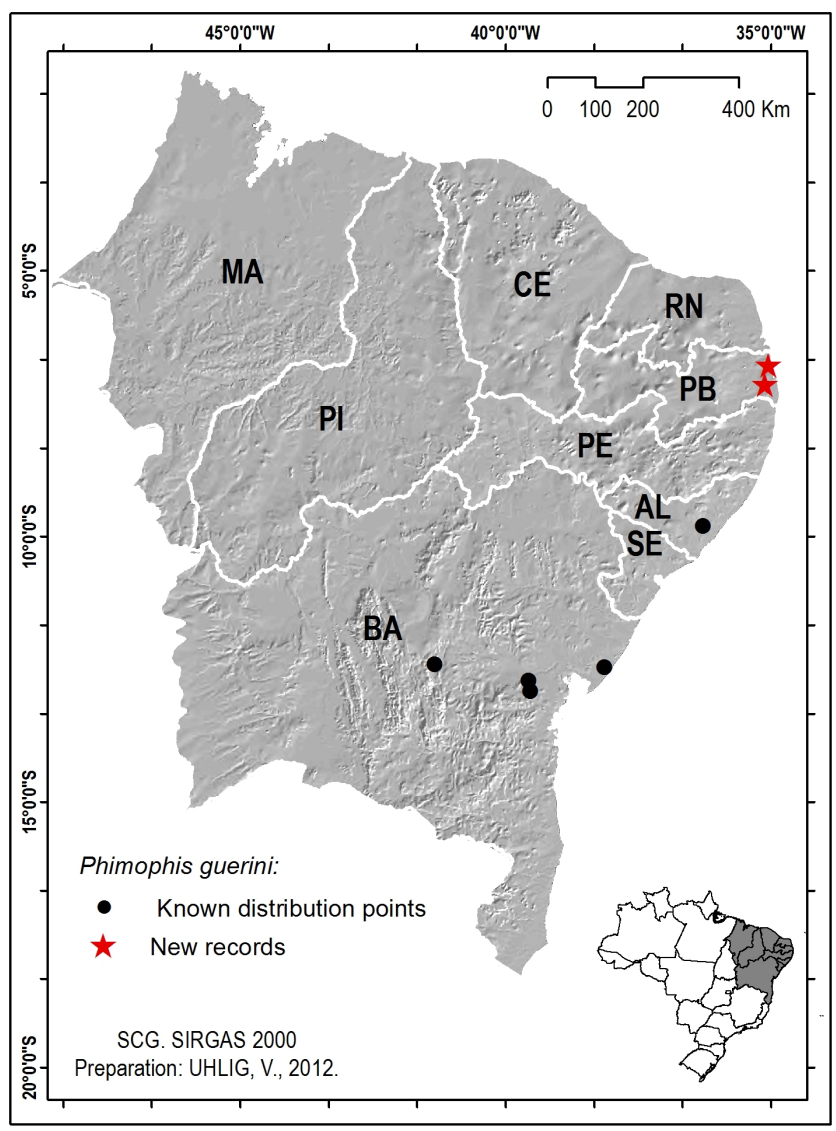

FIGURE 2. Map showing the distribution of Phimophis guerini in the coastal region of northeastern Brazil.

ACKNOWLedgments: The authors would like to thank the Programa de Pós-graduação em Ciências Biológicas, Conselho Nacional de Desenvolvimento Científico e Tecnológico (CNPq) for financial support. We thank the directors of Companhia Usina São João for support. We are in debt to Mr. Valdecy Xavier da Silva and his sons Valdilson and Valdemilson da Silva for field support. The curator of the Zoology Museum of the Santa Cruz State University, Antônio Jorge Suzart Argôlo, for keeping the voucher specimen and confirming the species identification and to Vivian Uhlig who kindly constructed the map.

\section{Literature Cited}

Bérnils, R.S and J.C. Moura-Leite. 2010. The contribution of Andreas Mayer for the natural history of the State of Paraná, Brazil. Brazilian Archives of Biology and Technology 53: 431-435.

França, F.G.R., D.O. Mesquita, C.C. Nogueira and A.F.B. Araújo. 2008. Phylogeny and ecology determine morphological structure in a snake assemblage in the Central Brazilian Cerrado. Copeia 2008(1): 20-36

França, F.G.R., D.O. Mesquita, C.C. Nogueira and G.R. Colli. 2006. A checklist of snakes from amazonian savannas in Brazil, housed in the Coleção Herpetologica da Universidade de Brasília, with new distribution records. Occasional Papers Sam Noble Oklahoma Museum of Natural History (17): 1-13.

Freitas, M.A. 2003. Serpentes Brasileiras. Lauro de Freitas: Malha-desapo-publicações. 160 p.

Grazziotin, F.G., H, Zaher, W.M. Robert, G. Scrocchi, M.A Benavides, Y.P. Zhang and S.L. Bonatto. 2012. Molecular phylogeny of the New World Dipsadidae (Serpentes: Colubroidea): a reappraisal. Cladistics 2012(1): 1-23

Juncá, F.A. 2005. Anfíbios e Répteis; p. 339-376. In F.A. Juncá, L. Funch and W. Rocha. (org.). Biodiversidade e Conservação da Chapada Diamantina. Brasília: Ministério do Meio Ambiente.

Lisboa, B.S., Araujo-Neto, J.V., Tiburcio, I, C.S., Silva, S.T. Geographic Distribution. Phimophis guerini. Herpetological Review 42 (4): 573574.

Peters, J.A. and B. Orejas-Miranda. 1970. Catalogue of the Neotropical Squamata, Part I. Snakes. United States National Museum Bulletin 297: 1-347.

Recorder, R and C. Nogueira. 2007. Composição e diversidade de répteis na região sul do Parque Nacional Grande Sertão Veredas, Brasil Central. Biota Neotropica 7(3): 267-278.

Rodrigues, M.T. 1993. Herpetofauna of paleoquaternary sand dunes of the middle Sao Francisco river: Bahia: Brazil. VI. Two new species of Phimophis (Serpentes: Colubridae) with notes on the origin of psammophilic adaptations. Papéis Avulsos de Zoologia. 38(11). 187 198.

Sawaya, R.J., O.A.V. Marques and M. Martins. 2008. Composition and natural history of a Cerrado snake assemblage at Itirapina, São Paulo state, southeastern Brazil. Biota Neotropica 8: 129-151.

Tipton, B.L. 2005. Snakes of Americas: checklist and lexicon. Florida: Krieger Public Company. 477 p.

Vitt, L.J., J.P. Caldwell, G.R. Colli, A.A. Garda, D.O. Mesquita, F.G.R. França, D.B. Shepard, G.C. Costa, M.M. Vasconcellos and V.N. Silva. 2005. Uma Atualização do Guia Fotográfico dos Répteis e Anfíbios da Região do Jalapão no Cerrado Brasileiro. Special Publications in Herpetology Sam Noble Oklahoma Museum of Natural History 2: 1-24.

RECEIVED: March 2012

ACCEPTED: July 2012

Published ONLINE: September 2012

EDITORIAL RESPONSIBILITY: Ross MacCulloch 